\title{
A Tourism Models Based on Local Wisdom as A Strategy for Poverty Alleviation (A Case from the Village In Indonesia)
}

\author{
Pahrudin ${ }^{1 *}$, L Liu ${ }^{2}$, S Muzayyanah ${ }^{1}$, I Kamil ${ }^{3}$ \\ ${ }^{1}$ Department of Business Administration Taiwan Industry, Chaoyang University Of Technology, \\ Taichung, Taiwan \\ ${ }^{2}$ Department of Leisure Service and Management, Chaoyang University of Technology \\ ${ }^{3}$ Economic Education Program, Faculty of Social and Economic Universitas Hamzanwadi, \\ Selong, West Nusa Tenggara, Indonesia \\ "rudipahru@gmail.com
}

\begin{abstract}
This study aims to determine the model of village development based on local wisdom as a poverty alleviation strategy. This research was conducted in the tourist village of Mas-Mas North Batukliang, Central Lombok. Sample this research is 20 people. The research sample was determined by snowball Throwing, and data includes primary and secondary data. Data were collected through library research methods, observation, in-depth interviews, and documentation. Data analysis techniques used in this research are case studies. The results showed that the tourism model based on economic potential could contribute to poverty reduction and the helplessness of the poor. Therefore further development of this model is needed to realize community independence in the village, especially increasing the involvement and active participation of residents in various activities to improve, prosperity and the use of tourist villages by the community and local government.
\end{abstract}

Keywords: Tourism models, poverty alleviation, poverty alleviation

\section{Introduction}

Indonesia is a country that has many islands and is rich in different cultures, races, ethnicities and ethnicities. Tourism is one of priority sectors. Tourism is a powerful force of change in the economy in both the developed and in the least developed countries [1]. The natural wealth and potential of the region do not balance with the level of welfare of the people Indonesia. Humans as a macrocosm are an inseparable unity, ecological wisdom with the local community to realize prosperity requires harmonization both of them [2] [3] . Indonesia is a developing country that has a role in reducing poverty through tourism. Tourism's special issue on tourism and poverty reduction follows, and four main themes are explored: development agency strategies and approaches, governance and biodiversity conservation, the assessment of tourism impacts and value chain analysis, and inter-sectoral linkages [4].

The Central Statistics Agency (BPS) noted that Indonesia experienced the lowest point in terms of the percentage of poverty since 1999, which was 9.82 per cent in March 2018.[5] With a poverty percentage of 9.82 per cent, the number of poor people or those who per capita expenditure per month were below the poverty line reached 25.95 million people. In rural 
areas, the level of the poor reaches $>69 \%$ classified as weak and work in the agricultural sector. Tourism activities by utilizing local resources began to be developed based on sustainable economic goals, supporting environmental conservation efforts, and improving the welfare of local people [6].

One area that is currently being focused on regional development is the Mas-Mas Village in Batukliang District, Central Lombok Regency West Nusa Tenggara, Indonesia. This village has a population of around 3197 men and 3308 women with a percentage of development of $0.38 \%-3.34 \%$ and a total of 2091 households.

The livelihoods of the people in Mas-Mas Village are mostly farmers, craftsmen (handcraft), and animal husbandry so that the population is highly dependent on natural conditions. The total number of family heads in mas-mas villages is 2091 families. The economic condition of Mas-Mas villagers is middle to lower level with a stable level of welfare. This study aims to determine the model of village development based on local wisdom as a poverty alleviation strategy.

\section{Method}

This type of research used in this research is descriptive qualitative research (naturalistic paradigm). Research that produces descriptive data in the form of written words from people and observable behaviour [7]. Descriptive Qualitative Research that explains about the conditions of the development of tourism models based on local wisdom in poverty alleviation in Mas-Mas village, North Batukliang District, Central Lombok Regency. The data validity test uses data triangulation. Data triangulation is checking the level of trust of research results with data collection techniques.[8]. Data collection techniques using literature study, observation, in-depth interviews with community participatory approaches and documentation. The population is 20 people. The research sample was determined by snowball throwing sample, and data includes primary and secondary data.

\section{Results And Discussion}

\subsection{Regional Potential}

Physical Potential

Mas-Mas Village is one of the tourist villages located in the middle of the island of Lombok precisely located in the District of North Batukliang, Central Lombok district. MasMas village has an area of $3.70 \mathrm{Km}$ which has a population of 6,505 people consisting of 3,197 inhabitants of the male population and 3,308 inhabitants of the female population. There are 1,085 poor households out of a total of 2,091 households living spread out over 11 regions. There are Goa region, Lowang Lawe region, Batulilih region, Punikasih region, Selusuh region, Senurus region, Antak region, Senyiur Region, Keranji region, Gelogor region, Selojan region. Characteristics of respondents according to age in the Mas-Mas tourist village include various age groups. The opportunities for involvement in tourism development can be for various age groups. In Mas-Mas Tourism Village the age group is dominated by 30-39 years which is equal to $50.0 \%$.

\subsection{Non Physical Potential}


Characteristics of respondents according to education in the Mas-Mas Tourism Village were dominated by graduates University at $40.0 \%$. The education level of respondents involved in tourism development dominate at the level of tertiary education. The difference in the education level of respondents will undoubtedly affect the management and development of tourism villages. The higher level of education of respondents, the management and development of tourism villages will be better.

The main livelihoods of respondents varied. In this case, the involvement in the development of the tourism village made as a side (additional) livelihood. Entrepreneurs and farmers dominated the main livelihoods of respondents in the Mas-Mas Tourism Village, respectively $45.0 \%$ and $30.0 \%$. The primary income of the respondent's household in MasMas Tourism Village around IDR 1,200,000 / month, which is $45.0 \%$. Respondents' household income from tourism activities is mostly IDR $300,000 /$ month, which is $70.0 \%$. The low household income of respondents from tourism activities is possible because of the still low number of tourist visits.

\subsection{Village Tourism and Local Wisdom Activities}

The tourist can see daily activities of the community start from ploughing the fields and planting rice seeds at any given time at the village. Besides, tourism also can be enjoyed by the reservoir or named Embung (reservoir) Dao in the village with natural conditions. For the traditional arts, the visitors can see several traditional arts like Nyaer, Islamic culture, gambus and gendang Belek. The tourists can be enjoyed traditional art at certain times. That is what we are currently striving to maintain and try to show. (Interview of Habiburrahman Yusuf Head of Village Mas-mas: May 6, 2019) ". Animal husbandry activities, environmental cleanliness and natural beauty, are part of the mas-mas village tour package for tourists. Tourism base on community has a positive impact on social activity and participation. There is a significance relationship between tourism's effects of community and participation degree [9].

\subsection{Local Wisdom based Tourism Village Development Strategy}

Mas-mas tourism village development strategy based on local wisdom refers to the physical and non-physical potential is developed about the uniqueness of each village. $\mathrm{Mr}$ Sapran Habib revealed in an interview that. "The decision to declare themselves as a tourist village means that all components of the community agree, understand, understand what the tourist village is. The community is aware of their existence in a tourist village, including being aware of accepting others as guests/tourists in their village, and they must serve. (Interview May 10, 2019) ". Mas-Mas Tourism Village carries out a strategy by utilizing the potential of local wisdom such as people's daily activities, namely farming, animal husbandry, and traditional ceremonies. It needed the concept of rural tourism developmental strategies based on rural and local wisdom to promote their tourism potentials as a sustainable flagship program [10].

The development of a tourism village has a purpose in community Empowerment. Empowerment is the active role of the community, which is demanded to progress or not the tourist village. The active role here is in preparing to receive and serve guests or tourists who visit with the specialities will be presented to them. Without the active role of the community, there will be no slogan for developing the tourist village. The development of a tourism village involves the active role of various parties, especially the tourism village community deep local culture[11]. 
The development of sustainable tourism villages and the preservation of natural resources requires community participation. Therefore a strategy for developing a sustainable tourism village by paying attention to the preservation of natural resources is essential to maintain the stability of the quality of the environment. Its depand on other researchers saying thats Current community-based tourism discourses resonate with the reality on the ground [12].

The development of a tourism village is successful in its management if the quality of the environment improves. Tourist Village has a goal to improve the economy of the local community. The development of a tourist village must professional managed without prejudice to the preservation of existing natural resources. Packaging and tour packages need to plan and managed correctly so that a tourist village has a sale value to tourists.

\subsection{Model of Tourism Development Based on Local Wisdom}

Based on an analysis of the area's potential both physical and non-physical potential as well as an analysis of tourism activities and local wisdom, a model of village tourism development can be made by offering villagers the daily habits of life. From waking up in the morning until going to bed at night, travellers come to feel the pulse of village life.

Breakfast with a village menu, to the rice field dressed as farmers, wearing a sarong in the afternoon and evening, even taking part in recitation or custom invitation also acted. Tourists who come must receive an explanation and fill in the guest book when they first enter the tourist village. Every guest gets a songket sarong to wear while in the village. The development of a local wisdom based tourism village involves the active participation of various parties, especially the tourism village community local culture [11].

Songket sarong means symbolic of religion and culture. The two meanings are the sign that there are guests of all the villagers. The songket cover is black with various patterned edges. Every guest who comes is subject to a stay and another fee of IDR 150,000 per day. Such a large fund includes the payment of a tour guide service of IDR. 40.000, the services of a woven maker group of Rp. 32 thousand, the services of a group making IDR 15,000 banana chips, a meal was serving 2-3 days IDR. 35.000 and the cost of washing the sarong worn by the guest IDR. 20.000 thousand. Interestingly, the poor, school or madrasa, village and village treasury also get an average of around 5-10 percent.

\subsection{Poverty Alleviation Strategies and Community Empowerment}

Strategies in poverty alleviation and empowerment of the rural poor by making the community the subject of the development of a tourism village and utilizing the natural and cultural potential or people's daily lives as tourist objects. Poverty Alleviation is an effort or program that should place the community as a subject in every program so that community welfare can realize immediately. Poverty alleviation approaches so far have not paid attention to the role of the poor themselves. This step does not provide significant results so that a poverty alleviation approach is needed that places the poor as subjects not as objects [13]. Village development tourism can give a contribution to the welfare of the community. Mapping the potential can be used as a tourism attraction and conducting training to the local community. Empowerment of the community will become the primary key for tourism development because of the empowerment and involvement of the population in tourism development. The village where tourism is developed will participate in keeping their culture and nature so that in the end the sustainable tourism development will be reached and maintain [14]. Community Empowerment is the key of developing society and based on Community Based on enterprise to give impact reducing poverty [15]. 
Mas-Mas tourism village makes tour packages for tourist. Packaging tour from farm tourism by utilizing community agricultural land in the Langga Lawe region, raising livestock by utilizing community farmland in the Senurus region, seeing the Vegetable garden in the Selusuh hamlet, visiting the school site in the village of Mas-Mas, surround the natural beauty of Embung Dao in the village of Senurus, see and learn the craft of ketak in the Antak-Antak region and see the process of making traditional food. On the other side, the participation of the community and the private sector is beneficial in tourism activities with the ultimate goal being to reduce poverty. Effective ways in which national planning can both encourage private sector actors to support poverty reduction and facilitate the involvement of wider sectors of society in tourism development [16]. However, the most important things is tourism how the donor funding like project and give impact to welfare of community. According to statement projects can indeed alleviate poverty and develop financial and cultural capital, private sector tourism enterprises also have an essential role in poverty alleviation [17]. On other hand, needed of framework for Sustainable Tourism as an effective tool for Eliminating Poverty [18].

\section{Conclusions}

From the results and discussion, Mas-Mas tourism villages can provide a positive contribution to the community in reducing poverty and increasing community income based on local wisdom. The income received by the community proves this. The other side of the tourist village can encourage creative industries so that it benefits the community. Mas-mas village Lombok central West Nusa Tenggara can be as a model for developing natural and cultural tourism village which divided into several ways. Alternatively, the stages of development as follows: Awareness, Community involvement or capacity building, Assistance to the communit, Institutionalization is carried out in the framework of the management or management of tourism villages.

\section{References}

[1] Gumus F, Eskin I, Veznikli A N and Gumus M 2007 Availability of rural tourism for Gallipoli villages: the potentials and attitudes. International Tourism Biennial conference, Turkey, 157

[2] Gabriel. A Y 2006 Manfaat Kearifan Ekologi Terhadap Pelestarian Lingkungan Suatu Studi Etnoekologi di Kalangan Orang Biboki, Akademika Jurnal Kebudayaan Vol. 4, No. 1

[3] Anshoriy N and Sudarsono. 2008 Kearifan Lingkungan: dalam Perspektif Budaya Jawa. (Yogyakarta: Yayasan Obor Indonesia)

[4] Spenceley A and Meyer D 2012 Tourism and poverty reduction: theory and practice in less economically developed countries Journal of Sustainable Tourism 20 297-317

[5] Putera A D 2018 Persentase Kemiskinan Indonesia Terendah Sejak 1999 Kompas.com

[6] Fandali C 2001 Perencanaan Kepariwisataan Alam (Yogyakarta: Fakultas Kehutanan UGM)

[7] Maleong L J 2001 Metodologi penelitian Kualitatif (Bandung: PT. Remaja Rosdakarya.)

[8] Arikunto Suharsimi 2010 Prosedur Penelitian Suatu Praktik (Jakarta: Rineka Cipta)

[9] Eshliki S A and Kaboudi M 2012 Community Perception of Tourism Impacts and Their Participation in Tourism Planning: A Case Study of Ramsar, Iran Procedia - Social and Behavioral Sciences 36 333-41 
[10]Farhan H and Anwar K 2016 The Tourism Development Strategy Based on Rural and Local Wisdom JSD 9170

[11] Priyanto and Safitri D 2015 Pengembangan Potensi Desa Wisata Berbasis Budaya Tinjauan Terhadap Desa Wisata Di Jawa Tengah Jurnal Vokasi Indonesia Vol. 4, No 1

[12] Salazar N B 2012 Community-based cultural tourism: issues, threats and opportunities Journal of Sustainable Tourism 20 9-22

[13] Hastuti and Respati D 2009 Model Pemberdayaan Perempuan Miskin Berbasis Pemanfaatan Sumberdaya Perdesaan Upaya Pengentasan Kemiskinan di Perdesaan Lereng Merapi Selatan Journal Humaniora Vol 14, Nomor 1

[14] Sutawa G K 2012 Issues on Bali Tourism Development and Community Empowerment to Support Sustainable Tourism Development Procedia Economics and Finance 4 413-22

[15] Manyara G and Jones E 2007 Community-based Tourism Enterprises Development in Kenya: An Exploration of Their Potential as Avenues of Poverty Reduction Journal of Sustainable Tourism 15 628-44

[16] Scheyvens R and Momsen J H 2008 Tourism and Poverty Reduction: Issues for Small Island States Tourism Geographies $1022-41$

[17] Harrison D and Schipani S 2007 Lao Tourism and Poverty Alleviation: Community-Based Tourism and the Private Sector Current Issues in Tourism 10 194-230

[18]Zhao W and Ritchie J R B 2007 Tourism and Poverty Alleviation: An Integrative Research Framework Current Issues in Tourism 10 119-43 